\title{
A COMPARATIVE STUDY OF THE ANTIFUNGAL ACTIVITY OF ESSENTIAL OILS OF Varronia curassavica Jacq. OBTAINED BY DIFFERENT DISTILLATION METHODS
}

\author{
ESTUDO COMPARATIVO DA ATIVIDADE ANTIFÚNGICA DOS ÓLEOS \\ ESSENCIAIS DE Varronia curassavica Jacq. OBTIDOS POR DIFERENTES \\ MÉTODOS DE DESTILAÇÃO
}

\author{
Daniela Aparecida de Castro NIZIO $^{1 *}$; Arie Fitzgerald BLANK ${ }^{1}$; Fabiany de Andrade BRITO ${ }^{1}$; \\ Paulo Roberto GAGLIARDI ${ }^{1}$; Eduardo ALVES ${ }^{2}$; Maria de Fátima ARRIGONI-BLANK ${ }^{1}$ \\ 1. Universidade Federal de Sergipe, Departamento de Engenharia Agronômica, São Cristóvão, SE, Brasil, *danielanizio82@gmail.com; \\ 2. Universidade Federal de Lavras, Departamento de Fitopatologia, Lavras, MG, Brasil.
}

\begin{abstract}
This work aimed to compare the antifungal activity of the essential oil of Varronia curassavica obtained by hydrodistillation and microwave against the fungus Colletotrichum musae and verify the alterations caused by these extraction methods on the leaf surface. This study used four essential oil samples obtained by different methods, two by hydrodistillation [HD1 (1.0 L of water and $100 \mathrm{~min}$.) and HD2 (2.0 L of water and $140 \mathrm{~min}$.)] and two by microwave [MI1 (500W, $20 \mathrm{~min}$, without water) and MI2 (700W, $40 \mathrm{~min}$, with $50 \mathrm{~mL}$ of water added to fresh leaves)]. Essential oils concentrations of $0.05,0.1,0.5,1.0$, and $3.0 \%(\mathrm{v} / \mathrm{v})$ were tested in PDA medium. The mycelial growth of $C$. musae was evaluated by measuring the diameter, every 24 hours up to 144 hours after the beginning of the incubation. Untreated leaves and leaves treated with HD1 and MI1 were prepared for observation in a scanning electron microscope (SEM) LEO EVO 40. The most abundant compounds detected in the essential oil samples analyzed by gas chromatography were: shyobunol, germacrene D-4-ol, E-caryophyllene, bicyclogermacrene, and $\alpha$-cadinol. Up to 72 hours after the beginning of the incubation, C. musae presented no mycelial growth, even at the lowest essential oil concentration. Conversely, mycelial growth was detected in the control (PDA + DMSO) from 24 hours after incubation. At 144 hours after incubation, regardless of the concentration, the essential oil samples obtained by HD provided lower mycelial growth of $C$. musae $(1.49 \mathrm{~cm})$ when compared with samples obtained by MI $(1.80 \mathrm{~cm})$. This difference possibly occurred due to the reduction to less than half of the germacrene D-4-ol content in the samples obtained by MI. The four essential oil samples tested inhibited the mycelial growth and thus presented a inhibitory effect on C. musae. The SEM revealed more drastic changes on the surface of the leaf treated with MI than on those treated with HD. The essential oil of $V$. curassavica, mainly when obtained by hydrodistillation, has the potential for use in the control of C. musae.
\end{abstract}

KEYWORDS: Erva-baleeira. Extraction Methods. Colletrotrichum musae. Volatile oils.

\section{INTRODUCTION}

Commonly known as "erva-baleeira," Varronia curassavica (Jacq.) is a medicinal species originated in Brazil, used both in the folk medicine and in the pharmaceutical industry for the treatment of inflammation. Several studies have stated that the anti-inflammatory property of "erva-baleeira" is attributed to the presence of the sesquiterpene $\alpha$ humulene in the essential oil contained in the leaves (PASSOS et al., 2007; MEDEIROS et al., 2007; ROGÉRIO et al., 2009; PARISSOTTO et al., 2012).

Essential oils are plant metabolites, mostly consisting of a mixture of compounds, mainly mono and sesquiterpenes. However, within each species, the chemical composition may vary according to several factors, such as plant genetic characteristics, climatic conditions, soil characteristics, biotic interferences, besides the methods used at plant tissue processing and essential oil extraction (GOBBO-NETO; LOPES, 2007; VERMA et al., 2010). Among these factors, the extraction method determines the essential oil quality (TONGNUANCHAN; BENJAKUL, 2014).

If the extraction is improperly performed, the procedure may alter the chemical composition of the essential oil and alter its natural characteristics, such as color, aroma, taste, and viscosity. All these changes may result in the loss of the biological activity of this metabolite.

Although hydrodistillation is the most widely used method for the distillation of essential oils in the laboratory, new techniques have been proposed aiming mainly to reduce the extraction 
A comparative study...

time and the water and energy consumption. In this sense, microwave-assisted essential oil extraction has aroused the interest of the scientific community (SHAH; GARG, 2014) for allowing a high and faster reproducibility, simplified handling, and reduction in water and energy consumption. Nevertheless, the most appropriate extraction conditions for each species must be established. In a study carried out with $V$. curassavica, the authors reported that both methods, hydrodistillation and microwave, were efficient in the essential oil extraction; however, the essential oil chemical composition differed depending on the extraction method and condition (NIZIO et al., 2018b).

essential

Besides the anti-inflammatory properties of "erva-baleeira" other activities have been reported, such as antibacterial (MATIAS et al., 2010; PINHO et al., 2012; RODRIGUES et al., 2012) and antiprotozoal (NIZIO et al., 2018a). Studies have also reported its efficiency against phytopathogenic fungi (SILVA et al., 2012; HOYOS et al., 2012; SILVA et al., 2014; NIZIO et al., 2015).

Among the most critical fungal species in Brazil, Colletotrichum musae (Berk \& Curt.) von Arx. stands out for causing anthracnose, the primary disease responsible for the post-harvest deterioration of banana fruits during the transportation, storage, and commercialization stages (MORAES; ZAMBOLIM; LIMA, 2006; PESSOA et al., 2007), causing severe losses to farmers and traders (THANGAMANI et al., 2011). Despite the significant contribution of synthetic fungicides to reducing losses caused by fungal diseases, some characteristics, such as the persistence and toxicity of these products, have led to several environmental problems, affecting the human and animal health. Moreover, fungicide-resistant fungal races have emerged due to the indiscriminate use of synthetic fungicides (VERWEIJ et al., 2009; ARENDRUP et al., 2010; TATEISHI et al., 2014). Therefore, several plant species have been studied, and the essential oil of many of them have presented antifungal activity, such as Corymbia citriodora, Cymbopogon nardus (AGUIAR et al., 2014), Myrcia ovata (SAMPAIO et al., 2016), Myrcia
NIZIO, D. A. C. et al.

lundiana (ALVES et al., 2016; ALVES et al., 2018), Lippia alba (PEIXOTO et al., 2018), Curcuma longa (HU et al., 2017), and Mentha piperita (RACHITHA et al., 2017). These metabolites are considered as a safer alternative for the control of these pathogens since they are biodegradable and have low toxicity and low risk of developing resistance in microorganisms (RUSSO et al., 2013). Also, several essential oils have been classified as "Generally Recognized as Safe (GRAS)" by the FDA.

Thus, this work aimed to compare the antifungal activity of the essential oil of "ervabaleeira" obtained by hydrodistillation and microwave against the fungus Colletotrichum musae and verify the changes that these methods cause on the leaf surface after the essential oil extraction.

\section{MATERIAL AND METHODS}

This study used four essential oil samples obtained from the $V$. curassavica accession VCUR201, from the Active Germplasm Bank of Medicinal and Aromatic Plants of the Federal University of Sergipe (SISGEN Register number A8CCB3B).

Two samples were obtained by hydrodistillation (HD) in a modified Clevenger apparatus under different conditions: $1.0 \mathrm{~L}$ of water and 100 minutes of extraction (HD1); and 2.0 L of water and 140 minutes of extraction (HD2). In both situations, $100 \mathrm{~g}$ of fresh leaves and $3.0 \mathrm{~L}$ flasks were used. Two other samples were obtained by microwave (MI) (NEOS, Milestone, Italy), using 50 $\mathrm{g}$ of fresh leaves, under the following conditions: $500 \mathrm{~W}$ power level, 20 minutes of extraction, without adding water to the leaves (MI1); and 700W power level, 40 minutes of extraction, with $50 \mathrm{~mL}$ of water added to fresh leaves (MI2) (NIZIO et al., 2018b).

The analysis of the essential oil chemical composition was performed in a GC-MS/FID mass spectrometer (QP2010 Ultra, Shimadzu Corporation, Kyoto, Japan), coupled with an autosampler AOC-20i (Shimadzu), according to Nizio et al. (2018b). Table 1 shows the chemical composition of the essential oils used in this study.

Table 1. Chemical composition of the essential oil from Varronia curassavica extracted by hydrodistillation (HD) and microwave (MI) (according to NIZIO et al., 2018b).

\begin{tabular}{lcccccc}
\hline Compounds & RRI-o & RRI-1 & HD1 & HD2 & MI1 & MI2 \\
\hline & & \multicolumn{4}{c}{ Content (\%) of chemical compounds } \\
$\beta$-elemene & 1389 & 1389 & 1.23 & 0.97 & 1.05 & 0.93 \\
$E$-caryophyllene & 1422 & 1417 & 5.49 & 4.35 & 4.40 & 3.12 \\
$\alpha$-humulene & 1457 & 1452 & 1.80 & 1.43 & 1.49 & 1.21 \\
alloaromadendrene & 1465 & 1458 & 1.78 & 1.44 & 1.65 & 1.34
\end{tabular}


A comparative study...

NIZIO, D. A. C. et al.

\begin{tabular}{lcccccc} 
bicyclogermacrene & 1499 & 1500 & 5.63 & 4.55 & 5.08 & 4.21 \\
germacrene-D-4-ol & 1580 & 1574 & 11.40 & 10.36 & 4.09 & 4.73 \\
spathulenol & 1583 & 1577 & 1.16 & 1.13 & 0.00 & 0.00 \\
caryophyllene oxide & 1592 & 1582 & 1.34 & 1.34 & 2.45 & 2.17 \\
ledol & 1612 & 1602 & 3.71 & 3.88 & 3.78 & 4.10 \\
epi- $\alpha$-murulol & 1646 & 1640 & 2.76 & 3.92 & 2.79 & 3.87 \\
cubenol & 1650 & 1645 & 1.82 & 2.22 & 1.63 & 1.90 \\
$\alpha$-cadinol & 1660 & 1652 & 4.56 & 5.63 & 4.54 & 4.60 \\
shyobunol & 1705 & 1709 & 24.24 & 25.88 & 26.47 & 27.46 \\
methyl farnesoate $(2 E, 6 E)$ & 1776 & 1783 & 2.95 & 2.88 & 3.94 & 1.77 \\
farnesyl acetate $(2 Z, 6 E)$ & 1824 & 1821 & 0.00 & 0.00 & 2.50 & 3.60 \\
\hline Essential oil content $(\%)$ & \multicolumn{7}{c}{2.93} & 3.23 & 1.65 & 3.43 \\
\hline RRI-o: Relative Retention Index - observed; RRI-1: Relative Retention Index - literature. HD1= 1.0 L of water and 100 min.; HD2=2.0 \\
L of water and 140 min.; MI1= 500W, 20 min., without water; MI2= 700W, 40 min., with 50 mL of water added to the fresh leaves.
\end{tabular}

For the evaluation of the antifungal activity, a pure culture of the fungus Colletotrichum musae was obtained from the mycology collection of the Phytopathology Laboratory of the Federal University of Sergipe-UFS. The experimental design was completely randomized with three replications. Four essential oil samples were tested, two of them obtained by hydrodistillation, HD1 and HD2, and two obtained by microwave, MI1 and MI2. Essential oil concentrations of $0.05,0.1,0.5$, 1.0 , and $3.0 \%(\mathrm{v} / \mathrm{v})$ were tested.

Essential oils were solubilized in 1\% DMSO and homogenized in PDA culture medium (Potato Dextrose Agar, HIMEDIA). Solutions were then poured into $9.0 \mathrm{~cm}$-diameter Petri dishes. A $7 \mathrm{~mm}$ diameter disk containing mycelia of the fungus culture was superimposed in the center of the Petri dishes, which were then sealed, identified, and incubated in a B.O.D. chamber at $22 \pm 3{ }^{\circ} \mathrm{C}$, with a 12-hour photoperiod. Evaluations were performed by measuring the mycelial diameter (mean of two diametrically opposite measures), using a pachymeter, every 24 hours up to 144 hours after the beginning of the incubation. Petri dishes without essential oil, containing the BDA medium and the DMSO solvent, were used as the control.

The scanning electron microscopy (SEM) was used to observe the changes in the leaves subject to the different methods of essential oil extraction. Analyses were performed at the Laboratory of Electron Microscopy and Ultra Structural Analysis, in the Department of Phytopathology of the Federal University of Lavras
(UFLA), Lavras, MG. Leaves without any treatment and those treated with HD1 (1.0L of water and 100 minutes of distillation) and MI1 (500W, 20 minutes, without water) were used. Samples were fixed and prepared according to Alves et al. (2008), mounted on aluminum brackets (stubs), coated with gold (Balzers SCD 050 evaporator), and observed in a scanning electron microscope LEO EVO 40.

For the mycelial growth data, graphs were obtained from the mean diameter (mean \pm standard error of the mean) of the mycelial growth for each concentration used, in function of the incubation time, using the Graph Pad Prism ${ }^{\circledR}$ software. The analysis of variance (ANOVA) was performed from the data of the 144-hour evaluation, considering a factorial scheme, with four essential oil samples and five concentrations, by the Sisvar software. Means were compared by the Tukey's test at 5\% probability. Afterward, a histogram was generated using the Graph Pad Prism ${ }^{\circledR}$ software.

\section{RESULTS AND DISCUSSION}

Up to 72 hours after the beginning of the incubation, $C$. musae presented no mycelial growth, even at the lower concentrations. Conversely, mycelial growth was detected in the control after 24 hours of incubation (Figure 1). The four essential oil samples tested inhibited the mycelial growth and thus presented a inhibitory effect on C. musae. After 144 hours of incubation, the fungus of the control treatment reached the maximum mycelial growth and occupied the entire Petri dish $(9.0 \mathrm{~cm}$ diameter). 
A comparative study...

Concentration $3.00 \%$

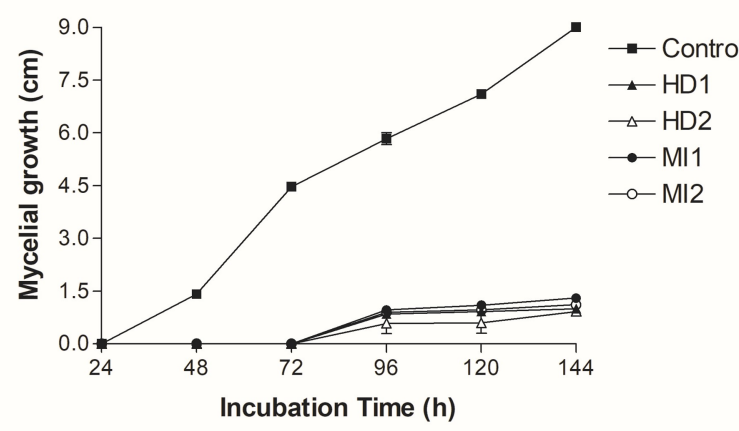

Concentration $\mathbf{0 . 5 0 \%}$

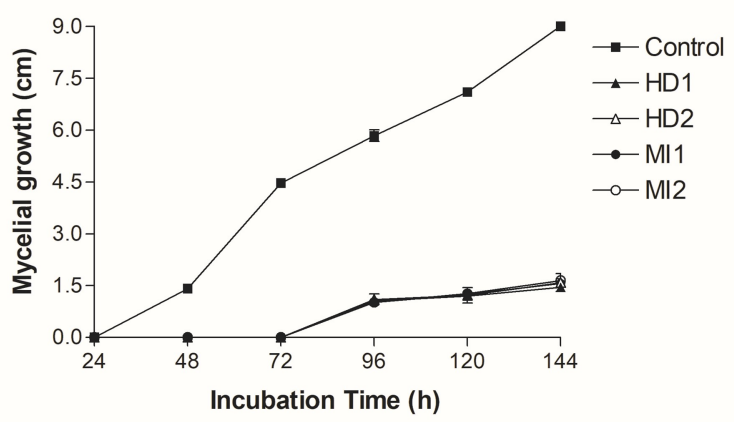

NIZIO, D. A. C. et al.

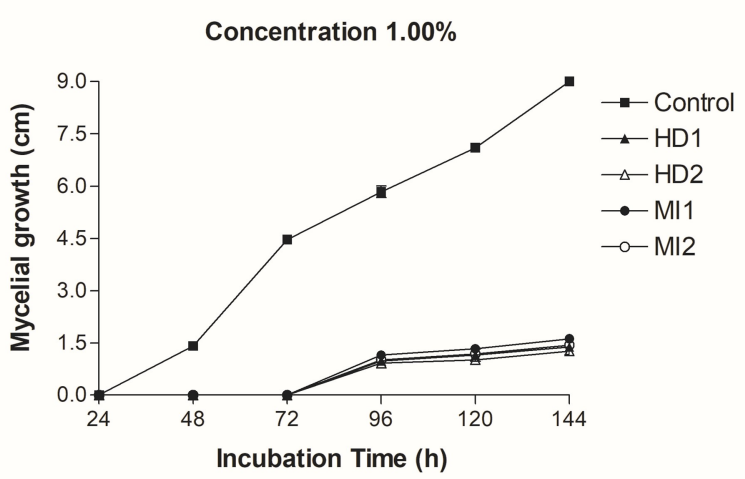

Concentration $0.10 \%$

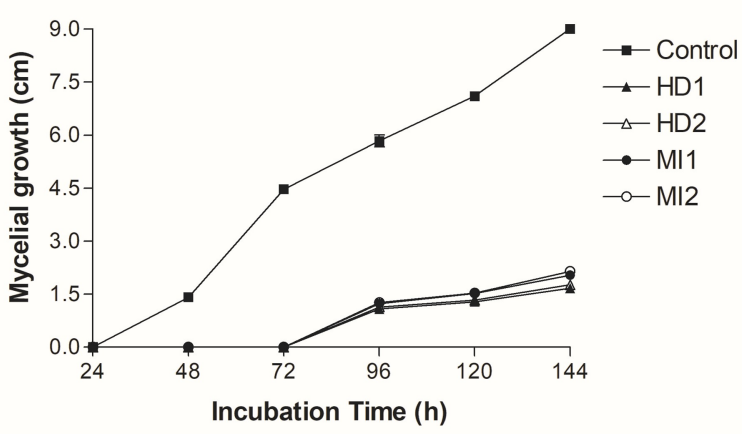

Concentration $\mathbf{0 . 0 5 \%}$

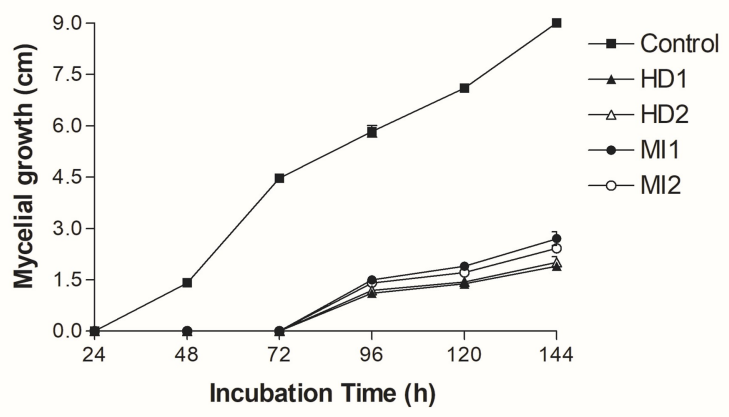

Figure 1. Mycelial growth of Colletotrichum musae in function of the incubation time and different concentrations of the essential oil of Varronia curassavica, obtained by hydrodistillation-HD and MI-microwaves.

$(\mathrm{HD} 1=1.0 \mathrm{~L}$ of water and $100 \mathrm{~min} ; \mathrm{HD} 2=2.0 \mathrm{~L}$ of water and $140 \mathrm{~min} ; \mathrm{MI} 1=500 \mathrm{~W}, 20 \mathrm{~min}$, without water; and MI2 = $700 \mathrm{~W}, 40 \mathrm{~min}$, with $50 \mathrm{~mL}$ of water).

The analysis of variance performed for the incubation time of 144 hours revealed the absence of significant interaction between the essential oil samples and the concentrations tested. Regardless of the concentration used, samples HD1 and HD2 showed significantly lower mycelial growth (1.48 and $1.51 \mathrm{~cm}$ ) when compared with samples MI1 $(1.75 \mathrm{~cm})$ and MI2 $(1.84 \mathrm{~cm})$ (Figure 2A). Regardless of the essential oil sample used, the concentration of $3.0 \%$ provided lower mycelial growth of C. musae $(1.08 \mathrm{~cm})$ when compared with the other concentrations (Figure 2B). Although the essential oil samples tested had no fungicidal effect, the maximum mycelial growth observed after 144 hours was $2.70 \mathrm{~cm}$ for the treatment MI1 at the lowest concentration tested $(0.05 \%)$, evidencing the existence of an inhibitory effect when compared with the control (Figure 1). 

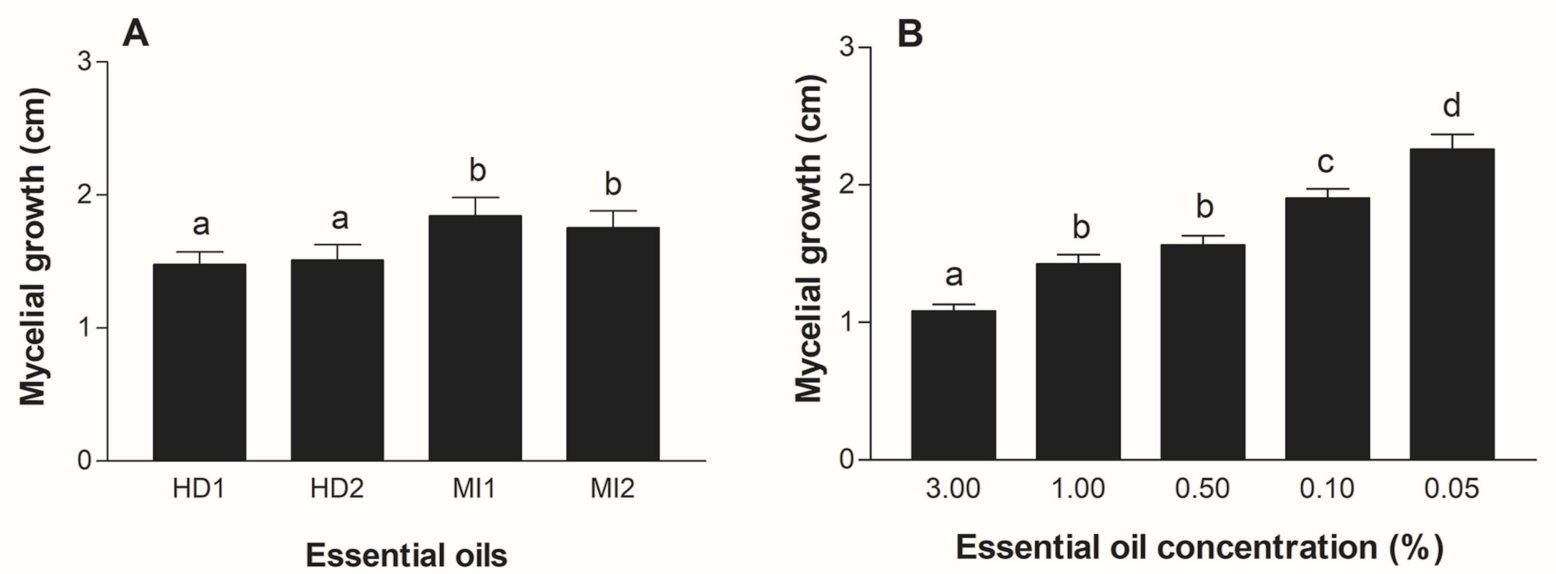

Figure 2. Mycelial growth of Colletotrichum musae in function of different samples (A) and different concentrations (B) of the essential oil of Varronia curassavica obtained by hydrodistillation (HD) and microwaves $(\mathrm{MI})$, after 144 hours of incubation $(\mathrm{HD} 1=1.0 \mathrm{~L}$ of water and $100 \mathrm{~min}$; HD2 $=2.0$ $\mathrm{L}$ of water and $140 \mathrm{~min}$; MI1 $=500 \mathrm{~W}, 20 \mathrm{~min}$, without water; MI2 $=700 \mathrm{~W}, 40 \mathrm{~min}$, with $50 \mathrm{~mL}$ of water). Bars followed by the same letter do not differ by the Tukey's test $(\mathrm{p}<0.05)$.

The differences in the chemical composition of the essential oil samples obtained by the two distinct extraction methods might have affected the inhibitory activity against $C$. musae. Among all the compounds, the highest difference was observed for germacrene D-4-ol, which was found at higher levels in essential oil samples obtained by hydrodistillation, with 11.40 and $10.36 \%$ for HD1 and HD2, respectively (Table 1). Also, the compound farnesyl acetate $(2 \mathrm{Z}, 6 \mathrm{E})$ was detected only in the essential oil obtained by the microwave extraction. The mycelial growth inhibition provided by the essential oil of $V$. curassavica can be attributed to the compounds present at higher levels, such as shyobunol, bicyclogermacrene, and germacrene D-4-ol. However, the presence of other compounds at lower levels can both potentiate the antifungal effect of the essential oil and reduce its toxicity.

Among the major compounds identified in the essential oil of "erva-baleeira" plants used in the present study, only germacrene-D-4-ol has been reported as presenting antifungal activity. The essential oil extracted from Zanthoxylum fagara fruits, containing germacrene D-4-ol as the major compound, exhibited strong activity against Colletotrichum acutatum (PRIETO et al., 2011). In Pinus nigra, the antimicrobial activity of essential oils against fungi and bacteria was attributed to the synergistic effect between some compounds and germacrene D-4-ol owing to the interaction of this compound with FtsZ binding pocket, which is an important enzyme related to cell division ( ŠARAC et al., 2014). Other toxic effects of the essential oils on microorganisms may be related to the damage caused by these metabolites to the cell walls, making them permeable (OLIVEIRA et al., 2011) and causing extravasation of the cellular content either by lipids oxidation, induced by some of the essential oils compounds (MONTANARI et al., 2012) or by the inhibition of the ergosterol synthesis (KEDIA et al., 2014). The essential oil of $V$. curassavica caused degenerative changes in Oidium eucalypti at a concentration of $0.25 \%(\mathrm{v} / \mathrm{v})$. The primary impairments observed were the lysis of the hyphal walls and the shrinking of conidia and conidiophores (SILVA et al., 2014).

When working with in natura foods, such as freshly harvested fruits, the most important thing is to inhibit the development of the disease and not necessarily to entirely eliminate the pathogen. A product that can inhibit the fungus growth, causing this process to occur more slowly, may be sufficient to preserve the fruit at the post-harvest, during the transportation, until reaching the final consumer, without presenting deterioration sings due to the disease. The absence of mycelial growth provided by the essential oil of "erva-baleeira" until three days after the beginning of the incubation shows the potential of this metabolite to control this pathogen in banana, favoring the fruit quality over its shelf life.

SEM was used to visualize the morphological changes in the leaves of "ervabaleeira" after the different extraction methods. Figure 3 shows the micrographs of untreated leaves (A), leaves treated with hydrodistillation extraction (B), and leaves treated with microwave extraction (C). In the untreated leaf, the globular glandular trichomes are intact and rounded, with no apparent 
damage. In the leaf subject to HD extraction, the glandular trichomes are wilted and deformed.
However, in the leaf treated with MI extraction, the trichomes are entirely disfigured.

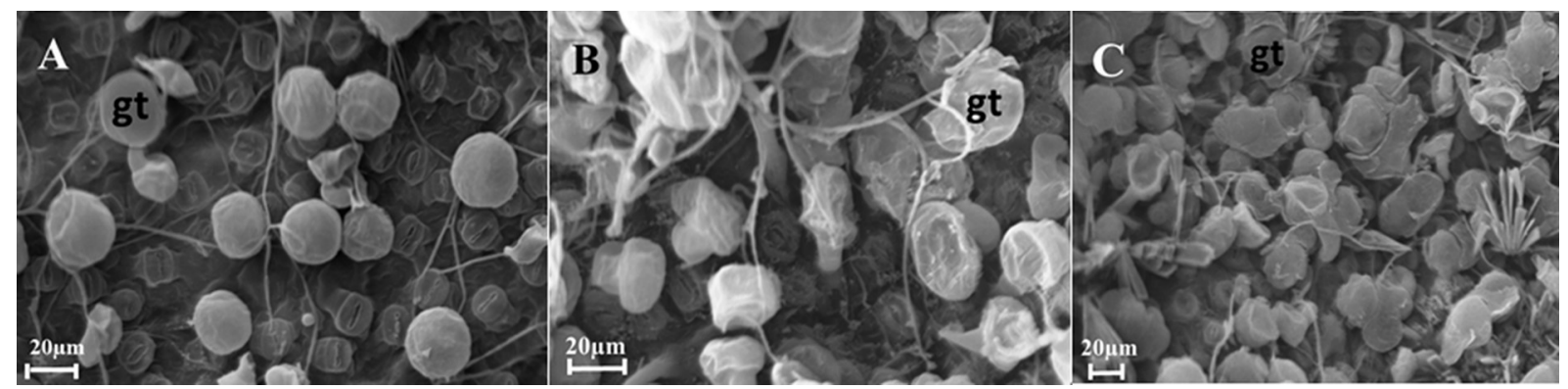

Figure 3. Scanning electron microscopy of leaves of Varronia curassavica: A- untreated; B- treated with hydrodistillation extraction (HD1 $=1.0 \mathrm{~L}$ water and $100 \mathrm{~min}$ ); $\mathrm{C}$ - treated with microwave extraction $(\mathrm{MI} 1=500 \mathrm{~W}, 20 \mathrm{~min}$, without water); gt $=$ glandular trichome.

The most drastic changes observed on the surface of the leaves treated with MI when compared with those treated with HD are due to the heating process of the former. In the microwave extraction, the heat transfers from the center to the external part of the sample by the absorption of the irradiation emitted by the equipment. This absorption leads to a rapid increase in the temperature and consequently an increase in the pressure inside the gland. This phenomenon exceeds the gland's expansion capacity and causes a faster rupture and release of the essential oil than when using HD extraction (LI et al., 2012; QI et al., 2014; GAVAHIAN et al., 2015), where the heat transfers from the outside to the inside and depends on the thermal conductivity of the equipment and the sample. In the HD method, the essential oil must permeate the cuticle to be extracted (SAHRAOUI et al., 2008). Materials subject to the microwave extraction were more damaged than those subject to the HD extraction, as in the case of fruits of Schisandra chinensis (MA et al., 2012) and leaves of Dryopteris fragrans (LI et al., 2012), Cajanus cajan (QI et al., 2014), and Rosmarinus officinalis (FARHAT et al., 2017).
The present results showed that the essential oil of $V$. curassavica obtained by hydrodistillation provided greater mycelial growth inhibition of $C$. musae when compared with that obtained by microwave extraction, possibly due to the alterations that the extraction methods caused to the chemical composition of this metabolite. Nevertheless, a considerably high mycelial growth inhibition was detected even at the lowest essential oil concentration obtained by the microwave extraction, compared with the control. The present study also revealed that the microwave-assisted essential oil extraction causes more drastic changes to the leaf surface, especially in glandular trichomes, when compared with hydrodistillation extraction. The essential oil of $V$. curassavica presents the potential of use to control the fungus $C$. musae. Nevertheless, in vivo studies must be performed by applying the essential oil to banana fruits.

\section{ACKNOWLEDGMENTS}

The authors thank CNPq, FAPITEC/SE, CAPES, FINEP, and RENORBIO for their financial support for this work.

RESUMO: O objetivo do trabalho foi comparar a atividade antifúngica do óleo essencial de Varronia curassavica obtido por hidrodestilação e micro-ondas frente ao fungo Colletotrichum musae e verificar as alterações que esses métodos de extração causam na superfície da folha. Quatro amostras de óleo essencial obtidas em diferentes condições foram utilizadas. Sendo duas por hidrodestilação, HD1 (1,0 L de água e 100 min.) e HD2 (2,0 L de água e $140 \mathrm{~min}$ ); e duas por micro-ondas, MI1 (500W, $20 \mathrm{~min}$. sem adição de água) e MI2 (700W, $40 \mathrm{~min}$. com adição de $50 \mathrm{~mL}$ de água às folhas frescas). Foram testadas as concentrações 0,05 ; 0,$1 ; 0,5 ; 1,0$ e $3,0 \%$ (v/v) de óleo essencial em meio BDA. O crescimento micelial do C. musae foi avaliado por medições do diâmetro, a cada 24 horas até 144 horas após o início da incubação. Folhas sem qualquer tratamento e após os tratamentos HD1 e MI1 foram preparadas para observação em microscópio eletrônico de varredura (MEV) LEO EVO 40. Os compostos mais abundantes nas amostras de óleo essencial analisadas por cromatografia gasosa foram: shyobunol, germacreno D-4-ol, E-cariofileno, biciclogermacreno e $\alpha$-cadinol. Até 
A comparative study...

NIZIO, D. A. C. et al.

72 horas após o início da incubação, não foi observado nenhum crescimento micelial do C. musae, mesmo nas concentrações mais baixas de óleo essencial, enquanto, para o controle (BDA + DMSO), foi observado crescimento do fungo a partir de 24 horas. Após 144 horas, independentemente da concentração, as amostras de óleo essencial obtidas por HD proporcionaram menor crescimento micelial do C. musae $(1,49 \mathrm{~cm})$ quando comparadas às amostras obtidas por MI $(1,80 \mathrm{~cm})$. Possivelmente essa diferença ocorreu devido à redução para menos da metade, do teor de germacreno D-4-ol, nas amostras obtidas por MI. As quatro amostras de óleo essencial testadas foram capazes de inibir o crescimento micelial, apresentando portanto, um efeito inibitório sobre o C. musae. Alterações mais drásticas observadas através da MEV foram visualizadas na superfície da folha submetida ao processo de extração por MI em comparação à HD. O óleo essencial de $V$. curassavica, sobretudo o obtido por hidrodestilação, apresenta potencial para o controle de C. musae.

PALAVRAS-CHAVE: Colletotrichum musae. Erva-baleeira. Métodos de extração. Óleos voláteis.

\section{REFERENCES}

AGUIAR, R. W. S.; OOTANI, M. A.; ASCENCIO, S. D.; FERREIRA, T. P. S.; SANTOS, M. M.; SANTOS, G. R. Fumigant Antifungal Activity of Corymbia citriodora and Cymbopogon nardus Essential Oils and Citronellal against Three Fungal Species. Hindawi Publishing Corporation, The Scientific World Journal, v. 2014, p. 1-8, 2014. http://dx.doi.org/10.1155/2014/492138

ALVES, E.; LEITE, B.; MARUCCI, R. C.; PASCHOLATI, S. F.; LOPES, J. R. S.; ANDERSEN, P. C. Retention sites for Xylella fastidiosa in four sharpshooter vectors (Hemiptera: 309 Cicadellidae) analyzed by scanning electron microscopy. Current Microbiology, v. 56, n. 5, p. 531-538, 2008.

http://dx.doi.org/10.1007/s00284-008-9119-7

ALVES, M. F.; NIZIO, D. A. C.; SAMPAIO, T. S.; NASCIMENTO JR., A. F.; BRITO, F. A.; MELO, J. O.; ARRIGONI-BLANK, M. F.; GAGLIARDI, P. R.; MACHADO, S. M. F.; BLANK, A. F. Myrcia lundiana Kiaersk native populations have different essential oil composition and antifungal activity against Lasiodiplodia theobromae. Industrial Crops and Products, Amsterdam, v. 85, p. 266-273, 2016. http://dx.doi.org/10.1016/j.indcrop.2016.03.039

ALVES, M. F.; BLANK, A. F.; GAGLIARDI, P. R.; ARRIGONI-BLANK, M. F.; NIZIO, D. A. C.; BRITO, F. A.; SAMPAIO, T. S. Essential oils of Myrcia lundiana Kiaersk and their major compounds show differentiated activities against three phytopathogenic fungi. Bioscience Journal, Uberlândia, v. 34, n. 5, p. 1200-1209, 2018. https://doi.org/10.14393/BJ-v34n5a2018-39429

ARENDRUP, M. C.; MAVRIDOU, E.; MORTENSEN, K. L.; SNELDERS, E.; FRIMODT-MØLLER, N.; KHAN, H.; MELCHERS, W. J. G; VERWEIJ, O. E. Development of azole resistance in Aspergillus fumigatus during azole therapy associated with change in virulence. PLOS ONE, v. 5, n. 4, 2010.

http://dx.doi.org/10.1371/journal.pone.0010080.g001

FARHAT, A.; BENMOUSSA, H.; BACHOUAL, R.; NASFI, Z.; ELFALLEH, W.; ROMDHANE, M.; BOUAJILA, J. Efficiency of the optimized microwave assisted extractions on the yield, chemical composition and biological activities of Tunisian Rosmarinus officinalis L. essential oil. Food and Bioproducts Processing, v. 105, p. 224-233, 2017. https://doi.org/10.1016/j.fbp.2017.07.011

GAVAHIAN, M.; FARAHNAKY, A.; FARHOOSH, R.; JAVIDNIA, K.; SHAHIDI, F. Extraction of essential oils from Mentha piperita using advanced techniques: Microwave versus ohmic assisted hydrodistillation.

Food and Bioproducts Processing, Birmingham, v. 9, p. 50-58, 2015.

https://doi.org/10.1016/j.fbp.2015.01.003

GOBBO-NETO, L.; LOPES, N. P. Plantas medicinais: fatores de influência no conteúdo de metabólitos secundários. Química Nova, v. 30, n. 2, p. 374-381, 2007. http://dx.doi.org/10.1590/S0100-

40422007000200026 
A comparative study...

NIZIO, D. A. C. et al.

HOYOS, J. M. A.; ALVES, E.; ROZWALKA, L. C.; SOUZA, E. A.; ZEVIANI, W. M. Antifungal activity and ultrastructural alterations in Pseudocercospora griseola treated with essential oils. Ciência e Agrotecnologia, Lavras, v. 36, n. 3, p. 270-284, 2012. http://dx.doi.org/10.1590/S1413-70542012000300002

HU, Y.; ZHANG, J.; KONG, W.; ZHAO, G.; YANG, M. Mechanisms of antifungal and anti-aflatoxigenic properties of essential oil derived from turmeric (Curcuma longa L.) on Aspergillus flavus. Food Chemistry, Norwich, v. 220, p. 1-8, 2017. https://doi.org/10.1016/j.foodchem.2016.09.179

KEDIA, A.; PRAKASH, B.; MISHRA, P. K.; DUBEY, N. K. Antifungal and antiaflatoxigenic properties of Cuminum cyminum (L.) seed essential oil and its efficacy as a preservative in stored commodities.

International Journal of Food Microbiology, v. 168, n.169, p.1-7, 2014.

https://doi.org/10.1016/j.ijfoodmicro.2013.10.008

LI, X. J.; WANG, W.; LUO, M.; LI, C. Y.; ZU, Y. G.; MU, P. S.; FU, Y. J. Solvent-free microwave extraction of essential oil from Dryopteris fragrans and evaluation of antioxidant activity. Food Chemistry, Norwich, v. 133, n. 2, p. 437-444, 2012. https://doi.org/10.1016/j.foodchem.2012.01.056

MA, C.; YANG, L.; ZU, Y.; LIU, T. Optimization of conditions of solvent-free microwave extraction and study on antioxidant capacity of essential oil from Schisandra chinensis (Turcz.) Baill. Food Chemistry, Norwich, v. 134, n. 4, p. 2532-2539, 2012. https://doi.org/10.1016/j.foodchem.2012.04.080

MATIAS, E. F.; SANTOS, K. K. A.; ALMEIDA, T. S.; COSTA, J. G. M.; COUTINHO, H. D. M. Atividade antibacteriana in vitro de Croton campestris A., Ocimum gratissimum L. e Cordia verbenacea DC. Revista Brasileira de Biociências, Porto Alegre, v. 8, n. 3, p. 294-298, 2010.

MEDEIROS, R.; PASSOS, G. F.; VITOR, C. E.; MAZZUCO, T. L.; PIANOWSKI, L. F.; CAMPOS, M. M.; CALIXTO, J. B. Effect of two active compounds obtained from the essential oil of Cordia verbenacea on the acute inflammatory responses elicited by LPS in the rat paw. British Journal of Pharmacology, London, v. 151, n. 5, p. 618-627, 2007. https://doi.org/10.1038/sj.bjp.0707270

MONTANARI, R. M.; BARBOSA, L. C. A.; DEMUNER, A. J.; SILVA, C. J.; ANDRADE, N. J.; ISMAIL, F. M. D.; BARBOSA, M. C. A. Exposure to Anacardiaceae volatile oils and their constituents induces lipid peroxidation within food-borne bacteria cells. Molecules, v. 17, n. 8, 9728-9740, 2012.

https://doi.org/10.3390/molecules17089728

MORAES, W. S.; ZAMBOLIM, L.; LIMA, J. D. Incidência de fungos em pós-colheita de banana (Musa spp.) "Prata-anã" (AAB). Summa Phytopathologica, Botucatu, v. 32, n. 1, p. 67-70, 2006.

https://doi.org/10.1590/S0100-54052006000100010

NIZIO, D. A. C.; BRITO, F. A.; SAMPAIO, T. S.; MELO, J. O.; SILVA, F. L. S.; GAGLIARDI, P. R.; ARRIGONI-BLANK, M. F.; ANJOS, C. S.; ALVES, P. B.; ALBERTO WISNIEWSKI-JUNIOR, A.; ARIE BLANK, A. F. Chemical diversity of native populations of Varronia curassavica Jacq.and antifungal activity against Lasiodiplodia theobromae. Industrial Crops and Products, Amsterdam, v. 76, p. 437-448, 2015. http://dx.doi.org/10.1016/j.indcrop.2015.07.026

NIZIO, D. A. C.; FUJIMOTO, R. Y.; MARIA, A. N.; CARNEIRO, P. C. F.; FRANÇA, C. C. S.; SOUSA, N. C.; BRITO, F. A.; SAMPAIO, T. S.; ARRIGONI-BLANK, M. F.; BLANK, A. F. Essential oils of Varronia curassavica accessions have different activity against white spot disease in freshwater fish. Parasitology

Research, v. 117, p. 97-105, 2018a. https://doi.org/10.1007/s00436-017-5673-x

NIZIO, D. A. C.; BLANK, A. F.; SAMPAIO, T. S; BRITO, F. A.; ANDRADE, T. M.; ARRIGONI-BLANK, M. F; MARIA, A. N. Distillation methods affect the chemical composition of Varronia curassavica Jacq. essential oil? Bioscience Journal, Uberlândia, v. 34, n. 3, p. 629-639, 2018b. http://dx.doi.org/10.14393/BJv34n3a2018-39372 
A comparative study...

NIZIO, D. A. C. et al.

OLIVEIRA, M. M. M.; BRUGNERA, D. F.; CARDOSO, M. G.; GUIMARÃES, L. G. L.; PICCOLI, R.H. Rendimento, composição química e atividade antilisterial de óleos essenciais de espécies de Cymbopogon.

Revista Brasileira de Plantas Medicinais, Botucatu, v. 13, n. 1, p. 8-16, 2011.

http://dx.doi.org/10.1590/S1516-05722011000100002

PARISSOTTO, E. B.; MICHIELIN, E. M. Z.; BISCARO, F.; FERREIRA, S. R. S.; FILHO, D. W.; PEDROSA, R. C. The antitumor activity of extracts from Cordia verbenacea D.C. obtained by supercritical fluid extraction. The Journal of Supercritical Fluids, v. 61, p. 101-107, 2012.

https://doi.org/10.1016/j.supflu.2011.08.016

PASSOS, G. F.; FERNANDES, E. S.; DA CUNHA, F. M.; FERREIRA, J.; PIANOWSKI, L. F.; CAMPOS, M. M.; CALIXTO, J. B. Anti-inflammatory and anti-allergic properties of the essential oil and active compounds from Cordia verbenacea. Journal of Ethnopharmacology, v. 110, n. 2, p. 323-333, 2007. https://doi.org/10.1016/j.jep.2006.09.032

PEIXOTO, M. G.; BLANK, A. F.; ARRIGONI-BLANK, M. F.; GAGLIARDI, P. R.; MELO, J. O.; NIZIO, D. A. C; PINTO, V. S. activity of essential oils of Lippia alba chemotypes and their major monoterpenes against phytopathogenic fungi. Bioscience Journal, Uberlândia, v. 34, n. 5, p. 1136-1146, 2018.

https://doi.org/10.14393/BJ-v34n5a2018-39385

PESSOA, W. R. L. S.; OLIVEIRA, S. M. A.; DANTAS, S. A. F.; TAVARES, S. C. C. H.; SANTOS, A. M. G. Efeito da temperatura e período de molhamento sobre o desenvolvimento de lesões de Colletotrichum musae em banana. Summa Phytopathologica, Botucatu, v. 33, n. 2, p. 147-151, 2007.

http://dx.doi.org/10.1590/S0100-54052007000200008.

PINHO, L.; SOUZA, P. N. S.; SOBRINHO, E.M.; ALMEIDA, A.C.; MARTINS, E.R. Antimicrobial activity of hydroalcoholic extracts from rosemary, peppertree, barbatimão and erva-baleeira leaves and from pequi peel meal. Ciência Rural, Santa Maria, v. 42, n. 2, p. 326-331, 2012. http://dx.doi.org/10.1590/S010384782012005000003

PRIETO, J. A.; PATIÑO, O. J.; DELGADO, W. A.; MORENO, J. P.; CUCA, L. E. Chemical composition, insecticidal, and antifungal activities of fruit essential oils of three Colombian Zanthoxylum species. Chilean Journal of Agricultural Research, v. 71, n. 1, p. 73-82, 2011. https://doi.org/10.4067/S071858392011000100009

QI, X. L.; LI, T. T.; WEI, Z. F.; GUO, N.; LUO, M.; WANG, W.; ZUA, Y. G.; FU, Y. J.; PENG, X. Solvent free microwave extraction of essential oil from pigeon pea leaves [Cajanus cajan (L.) Mill sp.] and evaluation of its antimicrobial activity. Industrial Crops and Products, Amsterdam, v. 58, p. 322-328, 2014. https://doi.org/10.1016/j.indcrop.2014.04.038

RACHITHA, P.; KRUPASHREE, K.; JAYASHREE, G.; GOPALAN, N.; KHANUM, F. Growth inhibition and morphological alteration of Fusarium sporotrichioides by Mentha piperita essential oil. Pharmacognosy Research, Mumbai, v. 9, n. 1, p. 74-79, 2017. http://dx.doi.org/10.4103/0974-8490.199771

RODRIGUES, F. F. G.; OLIVEIRA, L. G. S.; RODRIGUES, F. F. G.; SARAIVA, M. E.; ALMEIDA, S. C. X.; CABRAL, M. E. S.; CAMPOS, A. R.; COSTA, J. G. M. Chemical composition, antibacterial and antifungal activities of essential oil from Cordia verbenacea DC leaves. Pharmacognosy Research, Mumbai, v. 4, n. 3, p. 161-165, 2012. https://doi.org/10.4103/0974-8490.99080

ROGÉRIO, A. P.; ANDRADE, E. L.; LEITE, D. F. P.; FIGUEIREDO, C.; CALIXTO, J. B. Themed section:mediators and receptors in the resolution of inflammation. Preventive and therapeutic anti-inflammatory properties of the sesquiterpene $\alpha$-humulene in experimental airways allergic inflammation. British Journal of Pharmacology, London, v. 158, n. 4, p. 1074-1087, 2009. https://doi.org/10.1111/j.1476-5381.2009.00177.x 
A comparative study...

NIZIO, D. A. C. et al.

RUSSO, M.; SURACI, F.; POSTORINO, S.; SERRA, D.; ROCCOTELLI, A.; AGOSTEO, G. E. Essential oil chemical composition and antifungal effects on Sclerotium cepivorum of Thymus capitatus wild populations from Calabria, southern Italy. Brazilian Journal of Pharmacognosy, Curitiba, v. 23, n. 2, p. 239-248, 2013. https://doi.org/10.1590/S0102-695X2013005000017

SAHRAOUI, N.; VIAN, M. A.; BORNARD, I.; BOUTEKEDJIRET, C.; CHEMAT, F. Improved microwave steam distillation apparatus for isolation of essential oils comparison with conventional steam distillation. Journal of Chromatography A, v. 1210, n. 2, p. 229-233, 2008. https://doi.org/10.1016/j.chroma.2008.09.078

SAMPAIO, T. S.; NIZIO, D. A. C.; WHITE, L. A. S.; MELO, J. O.; ALMEIDA, C. S.; ALVES, M. F.; GAGLIARDI, P. R.; ARRIGONI-BLANK, M. F.; WISNIEWSKI- JUNIOR, A.; SOBRAL, M. E. G.; BLANK, A. F. Chemical diversity of a wild population of Myrcia ovata Cambessedes and antifungal activity against Fusarium solani. Industrial Crops and Products, Amsterdam, v. 86, p. 196-209, 2016. https://doi.org/10.1016/j.indcrop.2016.03.042

ŠARAC, Z.; MATEJIĆ, J. S.; STOJANOVIĆ-RADIĆ, Z. Z.; VESELINOVIĆ, J. B.; DŽAMIĆ, A. M.; BOJOVIĆ, S.; MARIN, P. D. Biological activity of Pinus nigra terpenes - Evaluation of FtsZ inhibition by selected compounds as contribution to their antimicrobial activity. Computers in Biology and Medicine, v. 54, n. 1, p. 72-78, 2014. https://doi.org/10.1016/j.compbiomed.2014.08.022

SHAH, M.; GARG, S. K. Application of $2^{\mathrm{k}}$ full factorial design in optimization of solvent-free microwave extraction of ginger essential oil. Journal of Engineering, Nasr City, v. 2014, p. 1-5, 2014.

http://dx.doi.org/10.1155/2014/828606

SILVA, A. C.; SOUZA, P. E.; MACHADO, J. C.; SILVA, B. M.; PINTO, J. E. B. P. Effectiveness of essential oils in the treatment of Colletotrichum truncatum-infected soybean seeds. Tropical Plant Pathology, Brasília, v. 37, n. 5, p. 305-313, 2012. http://dx.doi.org/10.1590/S1982-56762012000500001

SILVA, A. C.; SOUZA, P. E.; RESENDE, M. L. V.; SILVA JR., M. B.; RIBEIRO JR., P. M.; ZEVIANI, W. M. Local and systemic control of powdery mildew in eucalyptus using essential oils and decoctions from traditional Brazilian medicinal plants. Forest Pathology, Freising, v. 44, n. 2, p. 145-153, 2014.

http://dx.doi.org/10.1111/efp.12079

TATEISHI, H.; MIYAKE, T.; MORI, M.; SAKUMA, Y.; SAISHOJI, T. Effect of application timing of metconazole on Fusarium head blight development and mycotoxin contamination in wheat and barley. Journal of Pesticide Science, v. 39, n. 1, p. 1-6, 2014. https://doi.org/10.1584/jpestics.D12-077

THANGAMANI, P. R.; KUPPUSAMY, P.; PEERAN, M. F.; GANDHI, K.; RAGUCHANDER, T. Morphological and physiological characterization of Colletotrichum musae the causal organism of banana anthracnose. World Journal of Agricultural Sciences, v. 7, n. 6, p. 43-754, 2011.

TONGNUANCHAN, P.; BENJAKUL, S. Essential oils: extraction, bioactivities, and their uses for food preservation. Journal of Food Science, Chicago, v. 79, n. 7, p. 1231-1249, 2014.

http://dx.doi.org/10.1111/1750-3841.12492

VERWEIJ, P. E.; SNELDERS, E.; KEMA, G. H.; MELLADO, E.; MELCHERS, W. J. “Azole resistance in Aspergillus fumigatus: a side effect of environmental fungicide use?" The Lancet Infectious Diseases, v. 9, $\mathrm{n}$. 12, p. 789-795, 2009. https://doi.org/10.1016/S1473-3099(09)70265-8

VERMA, R. S.; RAHMAN, L.; VERMA, R. K.; CHAUHAN, A.; YADAV, A. K.; SINGH, A. Essential oil composition of menthol mint (Mentha arvensis) and pepper mint (Mentha piperita) cultivars at different stages of plant growth from Kumaon region of western Himalaya. Journal of Medicinal and Aromatic Plants, Anand, v.1, n. 1, p. 13-18, 2010. https://doi.org/10.1080/0972060X.2010.10643799 